\title{
| From cartilage to cancer: Translational research at the Norwegian Center for Stem Cell Research
}

Joel C. Glover

Director, Professor, Institute of Basic Medical Sciences, The University of Oslo Medical Faculty

Professor Joel Glover, Institute of Basic Medical Sciences, Sognsvannsveien 9 Domus Medica 0372 Oslo, Norway Phone: +47-228-512-30; fax +47-228-512-78.

E-mail: joel.glover@medisin.uio.no

\section{Keywords}

stem cell research, chondrocytes, gene engineering.
The report presents research activities at the Norwegian Center for Stem Cell Research located at Oslo University Hospital and the Institute of Basic Medical Sciences, University of Oslo. The Center's research focuses on hiPS cell production, differentiation, characterization and genetic modification (TALEN and CRISPR/CAS approaches), the role of epigenetics and DNA repair in stem cell differentiation, as well as neural imaging and functional assessment (including neuro-optogenetics). The University of Oslo Medical Faculty is establishing bilateral agreements with research and teaching institutions in St. Petersburg.

Repair of hyaline cartilage is among the current priorities in experimental and clinical research at the Center, in projects headed by group leader Jan Brinchmann. In vitro expanded chondrocytes are used for hyaline cartilage replacement, but they typically give rise to fibrous cartilage. The Brinchmann lab has implicated several factors relevant to in vitro chondrogenesis of human mesenchymal stem cells, as shown by high throughput mRNA profiling (Brinchmann et al., 2012) and is now collaborating with group leader Judith Staerk to use TALEN/CRISPR technology for targeted genetic manipulation. The CRISPR/Cas system can be used to direct Cas9 to specific genomic regions where it introduces DNA double-strand breaks. The regulatory system involves a non-coding guide RNA (gRNA), tracrRNA and the Cas9 protein. Staerk's group has used this system to develop human iPS/ ES cells with fluorescent reporters in the Brachyury, Flk1, CD34 and CD45 genetic loci, and is employing these in in vitro models of myelodysplastic syndrome, including genetic modifications introduced into hematopoietic stem cells. The Staerk group is also differentiating hES cells into blood cell precursors, and is also working on the expansion and maintenance of umbilical cord blood CD34+ cells.

The search for physiologically relevant tissue models includes the development of $3 \mathrm{D}$ cell culture systems representing new technological platforms for in vitro tissue engineering. Group leaders Gareth Sullivan and Joel Glover are applying 3D cell printing technology to develop multicellular assemblies of liver and neural tissue. Such 3D cellular systems applied to human stem cells and their derivatives can be utilized to investigate various heritable disorders affecting hepatocytes, neurons, cardiomyocytes etc.

In the field of oncology, the Center's efforts are currently focused on dendritic cell-based vaccine for glioblastoma, in a clinical project led by group leader Iver Langmoen together with group leaders Gunnar Kvalheim and Brinchmann. Therapeutic vaccination against autologous cancer stem cells has been used for decades. However, one may expect better efficiency of such treatment using gliioblastoma mRNA-transfected dendritic cells from glioblastoma patients. A Phase I/II trial of vaccine therapy with hTERT, survivin and glioblastoma stem cell-derived mRNA-transfected dendritic cells has been conducted. Among positive effects of such therapy are decreased tumor size and increased median progression-free survival time (PFS), which was 19.9 months (in patients treated with transfected dendritic cells) treatment) versus 7.9 (with standard treatment). 
The Center maintains two GMP cell production facilities for the establishment of autologous cell cultures and mRNA amplification, enabling GMP clinical production of human stem cells and their differentiated progeny performed under highly controlled conditions corresponding to EU Directives and Regulations.

Translational stem cell research has been defined as an area of national priority in Norway, leading to the establishment of the Center by an initiative from the Ministry of Health. The Center also maintains the National Core Facility for Production, Maintenance and Characterization of Human Pluripotent Stem Cells, the only such facility in Norway. This facility began using iPS cell technology in 2012 and its services are available to Norwegian and foreign researchers.

\section{References}

1. Herlofsen SR, Bryne JC, Høiby T, Wang L, Issner R, Zhang X, Coyne MJ, Boyle P, Gu H, Meza-Zepeda LA, Collas P, Mikkelsen TS, Brinchmann JE. Genome-wide map of quantified epigenetic changes during in vitro chondrogenic differentiation of primary human mesenchymal stem cells. BMC Genomics. 2013 Feb 15;14:105. doi: 10.1186/14712164-14-105.

2. Vik-Mo EO, Nyakas M, Mikkelsen BV, Moe MC, Due-Tønnesen P, Suso EM, Sæbøe-Larssen S, Sandberg C, Brinchmann JE, Helseth E, Rasmussen AM, Lote K, Aamdal S, Gaudernack G, Kvalheim G, Langmoen IA. Therapeutic vaccination against autologous cancer stem cells with $\mathrm{mR}$ NA-transfected dendritic cells in patients with glioblastoma. Cancer Immunol Immunother. 2013 Sep; 62(9):1499-1509.

\section{0т хряща к раковым опухолям: трансляционные исследования в норвежском Центре изучения стволовых клеток}

\section{Джоэл Гловер}

Директор, профессор, Институт фундаментальных медицинских наук, Медицинский факультет Университета Осло

Доклад представляет исследовательскую деятельность Норвежского центра изучения стволовых клеток, расположенного в Университетском госпитале Осло и Институте фундаментальных медицинских наук университета Осло. Работы Центра сосредоточены на продукции индуцированных полипотентных клеток, их дифференцировке, характеризации и генной модификации (методики TALEN и CRISPR/CAS), роли эпигенетики и репарации ДНК в дифференцировке стволовых клеток, а также в нейровизуализации и функциональной оценке, включая нейро-оптогенетику. Медицинский факультет Университета Осло заключает двусторонние соглашения с исследовательскими и учебными организациями Санкт-Петербурга.

Репарация гиалинового хряща сейчас является одной из основных задач экспериментальных и клинических исследований Центра в рамках проектов (руководитель - Ян Бринчманн). Размноженные in vitro хондроциты используются для замещения гиалинового хряща, но обычно они развиваются в фиброзный хрящ. Лаборатория Бринчманна выявила несколько факторов,

\section{Ключевые слова}

стволовые клетки, хондроциты, генная инженерия.

относящихся к хондрогенезу мезенхимных стволовых клеток человека in vitro, что было показано с помощью высокоразрешающего типирования мРНК (Brinchmann et al., 2012). В настоящее время идет сотрудничество с руководителем группы Джудит Стерк по применению технологий TALEN/CRISPR для направленных генетических манипуляций. Система CRISPR/Cas может использоваться для адресации Cas9 в конкретные области генома, где она осуществляет двунитевые разрезы ДНК. Регулирующая система включает в себя некодирующую «ведущую» РНК (gRNA), tracrRNA и белок Cas9. Группа Стерк применила эту систему для разработки человеческих полипотентных стволовых клеток (iPS/ES) с флуоресцентными маркерами в генных локусах Brachyury, Flk1, CD34 и CD45 и внедрила их в моделях in vitro миелодиспластического синдрома, включая генные модификации гемопоэтических стволовых клеток. Группа Стерк также осуществляет дифференцировку эмбриональных клеток человека в кроветворные предшественники, а также работает по экспансии и поддержании культур CD34+ клеток пуповинной крови. 